\title{
Analysis of AC-WC Design Material Using Reclaimed Asphalt Pavement
}

\author{
Sri Sunarjono ${ }^{1,2}$, Nurul Hidayati ${ }^{1,2, *}$, Mochamad Rivai Wisnu Ardianto ${ }^{2}$, Alfia Magfirona ${ }^{1}$ \\ ${ }^{1}$ Transportation Research Center, Faculty of Engineering, Universitas Muhammadiyah Surakarta, Indonesia \\ ${ }^{2}$ Department of Civil Engineering, Postgraduate Study Program, Universitas Muhammadiyah Surakarta, Surakarta, Indonesia
}

Received February 25, 2020; Revised May 20, 2020; Accepted May 29, 2020

Copyright $(2020$ by authors, all rights reserved. Authors agree that this article remains permanently open access under the terms of the Creative Commons Attribution License 4.0 International License

\begin{abstract}
The recycling technique using materials produced by Cold Milling Machine is a potential alternative to be applied to road maintenance in Indonesia. This study aims to investigate the properties of Reclaimed Asphalt Pavement (RAP) used as Asphalt Concrete Wearing Course (AC-WC) so that the proportion of additional fresh aggregate can be determined. This laboratory-scale study uses the material of RAP from Semarang Section A toll road sections and penetrated asphalt of $60 / 70$. The extraction analysis obtained asphalt content is between $3.50 \%-4.36 \%$, with abrasion of $29.04 \%$. RAP cannot be used directly but there is a need to add fresh aggregate so that the mixture meets the specifications. The proportion of the mixture is $30 \%$ of RAP, $18 \%$ of the fresh aggregate, $50 \%$ of rock ash, and $2 \%$ of Cement. The analysis shows that the mixture with optimum asphalt content $(5.7 \%)$ obtained $1188 \mathrm{~kg}$ of stability, $4.02 \%$ of VIM, $15.81 \%$ of VMA, $74.54 \%$ of VFWA, and $3.57 \mathrm{~mm}$ of flow. These values indicate that the mixture meets the revised version of the Technical Specifications of Bina Marga 2010. Therefore, it can be said that this mixture has high durability, good density, and is resistant to the possibility of bleeding.
\end{abstract}

Keywords AC-WC, RAP, Recycling Technique

\section{Introduction}

The existence of road as a vital part of infrastructure means it is the main pillar to support economic development at present (Magfirona, Hidayati, \& Sunarjono, 2017). Road pavement can be classified into two types, i.e. flexible pavement and rigid pavement. One example of flexible pavement construction is asphalt concrete (AC) which is formed from a combination of various sizes of aggregates that are bound by asphalt cement to produce a mixture that has a higher stiffness (Gudipudi \& Underwood, 2015). Mardhatila \& Zulkarnain (2013) stated that most of the flexible pavements had been damaged before reaching service life. Widodo et al (2013) also stated that the condition of the existing road network in Indonesia suffered from minor damage to severe damage which had reached nearly $40 \%$. In general, road damage is caused by several factors including climate, poor drainage, and overloading. These factors can cause cracking, distortion, wearing, bleeding, and pothole. According to Vo et al. (2019), the most common damage is cracking including hair cracking and alligator cracking. Road damage can be handled by an overlay technique (Mato, 2015). Widodo et al (2013) stated that this technique was sometimes less effective because the material used to repair the damage was not as good as the raw material pavement. The limitation of road materials (either aggregate or asphalt) in several regions in Indonesia is one obstacle to improving the performance of road infrastructure. This condition has an impact on the increasingly high costs of road construction and rehabilitation. Another alternative that can be done as an effort to overcome road damage is to extract the damaged layer using a cold milling machine as an overlay (Abraham \& Ransinchung, 2019). These materials are often used for routine road maintenance, and therefore need to be planned regularly and systematically (Thanya, Suweda, \& Putra, 2018). In the United States, the use of Reclaimed Asphalt Pavement (RAP) in hot-mix asphalt has been carried out on a large scale. According to Madrigal et al. (2017), Fattah et al. (2017), Kou et al. (2017), and Sunarjono (2006), the use of RAP in the mix is increasing rapidly along with the increasing environmental and economic problems of recycled materials. Pratico (2015) investigated RAP used for low traffic volume roads, and the results showed that the mechanical properties were satisfactory. Utilization of RAP is preferred over fresh aggregate given the increasing cost of asphalt, the lack of 
quality aggregates, and the need for pressure to preserve the environment (Qadi et al, 2007). The composition of RAP in asphalt mixture needs to be calculated carefully because it could affect the specific gravity, density of the mixture, and volumetric characteristics ((Huang et al, 2005 and Sunarjono, 2018). Reclaimed Asphalt Pavement (RAP) is a hot-mix material from cold milling machine with a certain additive to improve quality, prolong life and reduce early damage after being repaired (Luo, 2018 and Xiao, et al, 2017). Utilization of Cold Milling Machine without adding asphalt can potentially shorten the pavement life. If the asphalt content is lacking the bond between the aggregates will be easily loose, and if the asphalt content is too high, this condition is potential for bleeding. In asphalt pavement, the optimum asphalt content is very important because asphalt acts as a binding agent for asphalt and aggregates. Asphalt film layer on the aggregate serves to protect from exposure to weather and bind the aggregate with each other. The quality of the aggregate also affects the strength of the pavement, and the higher quality of the aggregate will produce higher stability of the pavement. Proper planning must be done so that the results of the demolition pavement material can be used for road maintenance. This study aims to investigate the Asphalt Concrete Wearing Course (AC-WC) mixtures that used RAP materials. The parameters of the durability of the mixture sought are based on Bitumen Film Thickness (BFT), Residual Stability, and Percentage Refusal Density (PRD).

\section{Method}

The study was conducted by comparing the test results of cold milling material extraction in the laboratory with the design specifications of hot-mix asphalt. The next step was conducting trials of adding aggregate and asphalt using the extracted material to obtain a suitable mixture with the specifications. The location of cold milling sampling is at Manyaran Toll Road, Semarang, Section A that can be seen in Figure 1. The research used two types of data, i.e. primary and secondary data. Primary data was related to the identification of RAP material consisted of the aggregates test, the proportion of mixed aggregates, optimum asphalt content, and Marshall Test. Secondary data (including Asphalt Shell 60/70 penetration) was obtained from previous research conducted at the Road and Traffic Engineering Laboratory, Faculty of Civil and Environmental Engineering ITB.

\section{Results and Discussion}

\section{Inspection of RAP Disassembly Materials}

Examination of RAP obtained asphalt content extracted between $3.5 \%-4.3 \%$, wear $29.04 \%$, Bulk specific gravity $2.607 \mathrm{gr} / \mathrm{cc}$, SSD specific gravity $2.644 \%$, apparent specific gravity $2.707 \mathrm{gr} / \mathrm{cc}$ and absorption $1.411 \%$. The results of the sieving analysis show that the RAP material did not meet the 2010 Bina Marga Technical Specifications $3^{\text {rd }}$ revision, which can be seen in Table 1 .

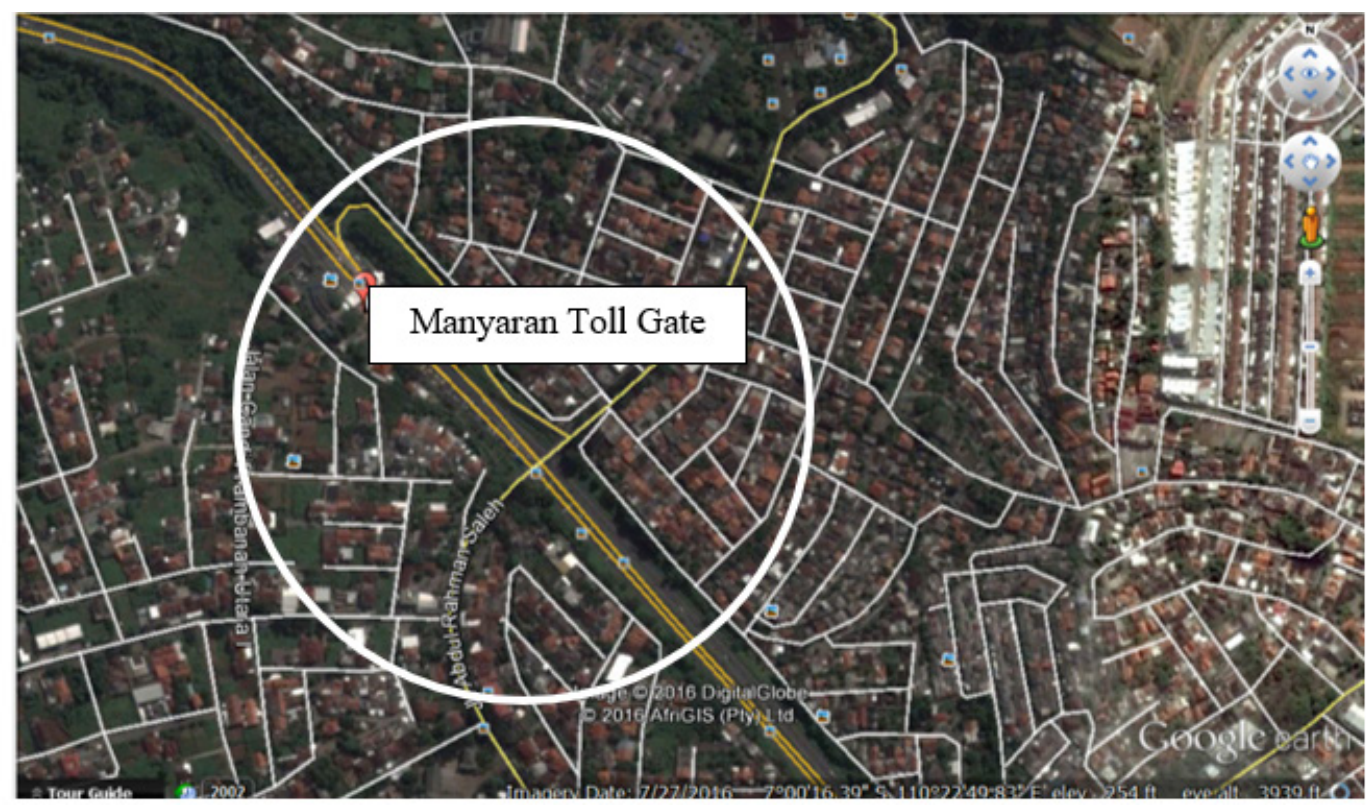

Figure 1. Location of cold milling sampling (Manyaran Toll Road Section - Semarang Section A) 
Table 1. Sieving analysis of the RAP material

\begin{tabular}{|c|c|c|c|c|c|c|c|c|c|}
\hline \multirow{2}{*}{\multicolumn{2}{|c|}{$\begin{array}{c}\text { Sieve } \\
\text { size }\end{array}$}} & \multirow{3}{*}{$\begin{array}{c}\text { Retained } \\
\text { weight } \\
\text { (gr) }\end{array}$} & \multirow{3}{*}{$\begin{array}{c}\text { Sample } 1 \\
\text { Retained } \\
(\%)\end{array}$} & \multirow{3}{*}{$\begin{array}{l}\text { Pass } \\
(\%)\end{array}$} & \multicolumn{3}{|c|}{ Sample 2} & \multirow{3}{*}{$\begin{array}{c}\text { Specification } \\
(\%)\end{array}$} & \multirow{3}{*}{$\begin{array}{c}\text { Average } \\
(\%)\end{array}$} \\
\hline & & & & & Retained & Retained & Pass & & \\
\hline Inchi & $\mathrm{mm}$ & & & & (gr) & $(\%)$ & $(\%)$ & & \\
\hline $1.5 "$ & 37.5 & 0.0 & 0.0 & 100.0 & 0.0 & 0.0 & 100.0 & & 100.0 \\
\hline 1" & 25.4 & 0.0 & 0.0 & 100.0 & 0.0 & 0.0 & 100.0 & & 100.0 \\
\hline $3 / 4 "$ & 19.1 & 0.0 & 0.0 & 100.0 & 0.0 & 0.0 & 100.0 & 100,0 & 100.0 \\
\hline $1 / 2^{\prime \prime}$ & 12.7 & 0.0 & 0.0 & 100.0 & 0.0 & 0.0 & 100.0 & $90-100$ & 100.0 \\
\hline 3/8" & 9.5 & 0.0 & 0.0 & 100.0 & 0.0 & 0.0 & 100.0 & $77-90$ & 100.0 \\
\hline$\# 4$ & 4.75 & 1351.4 & 78.6 & 21.36 & 1405.2 & 79.4 & 20.7 & $53-69$ & 21.0 \\
\hline \# 8 & 2.38 & 1598.8 & 93.0 & 7.0 & 1657.6 & 93.6 & 6.4 & $33-53$ & 6.7 \\
\hline \# 16 & 2.28 & 1635.8 & 95.2 & 4.8 & 1692.8 & 95.6 & 4.4 & $21-40$ & 4.6 \\
\hline \# 30 & 0.6 & 1645.6 & 95.8 & 4.2 & 1702.2 & 96.1 & 3.9 & $14-30$ & 4.1 \\
\hline \# $\mathbf{5 0}$ & 0.3 & 1649.8 & 96.0 & 4.0 & 1705.8 & 96.3 & 3.7 & $9-22$ & 3.8 \\
\hline \# 100 & 0.15 & 1655.2 & 96.3 & 3.7 & 1710.6 & 96.6 & 3.4 & $6-15$ & 3.5 \\
\hline \# 200 & 0.075 & 1700.4 & 99.0 & 1.1 & 1737.6 & 98.1 & 1.9 & $4-9$ & 1.5 \\
\hline \multicolumn{2}{|c|}{ Weight sample } & 1718.4 & & & 1771 & & & & \\
\hline
\end{tabular}

\section{Rejuvenating Aggregate Examination}

Aggregate examination $3 / 4$ " obtained $27.04 \%$ wear, bulk specific gravity 2,592 gr / cc, SSD specific gravity 2,622\%, Apparent specific gravity 2,674 gr / cc and absorption 1,185\%. The sieving analysis results can be seen in Table 2 .

Table 2. Aggregate $3 / 4$ " sieving analysis

\begin{tabular}{|c|c|c|c|c|c|c|c|c|}
\hline \multirow{2}{*}{\multicolumn{2}{|c|}{$\begin{array}{l}\text { Sieve } \\
\text { size }\end{array}$}} & \multirow{3}{*}{$\begin{array}{c}\text { Retained } \\
\text { weight } \\
\text { (gr) }\end{array}$} & \multirow{3}{*}{$\begin{array}{c}\text { Sample } 1 \\
\text { Retained } \\
(\%)\end{array}$} & \multirow{3}{*}{$\begin{array}{l}\text { Pass } \\
(\%)\end{array}$} & \multicolumn{3}{|c|}{ Sample 2} & \multirow{3}{*}{$\begin{array}{c}\text { Average } \\
(\%)\end{array}$} \\
\hline & & & & & Retained & Retained & Pass & \\
\hline Inchi & $\mathrm{mm}$ & & & & (Gram ) & $(\%)$ & $(\%)$ & \\
\hline $1.5 "$ & 37,5 & 0 & 0 & 100 & 0 & 0 & 100 & 100 \\
\hline 1" & 25,4 & 0 & 0 & 100 & 0 & 0 & 100 & 100 \\
\hline 3/4" & 19.1 & 0,00 & 0,00 & 100,00 & 0,00 & 0,00 & 100,00 & 100,00 \\
\hline 1/2" & 12.7 & 1.273 .2 & 39.7 & 60.3 & 1339.8 & 41.5 & 58.5 & 59.4 \\
\hline 3/8" & 9.5 & 2.578 .0 & 80.4 & 19.6 & 2530.8 & 78.3 & 21.7 & 20.7 \\
\hline$\# 4$ & 4.75 & 3.074 .4 & 95.8 & 4.2 & 3087.8 & 95.6 & 4.4 & 4.3 \\
\hline \# 8 & 2.38 & 3.097 .8 & 96.6 & 3.4 & 3113.2 & 96.4 & 3.6 & 3.5 \\
\hline \# 16 & 2.28 & 3.115 .8 & 97.1 & 2.9 & 3132.4 & 97.0 & 3.0 & 3.0 \\
\hline \# 30 & 0.6 & 3.130 .2 & 97.6 & 2.4 & 3147.6 & 97.4 & 2.6 & 2.5 \\
\hline \# $\mathbf{5 0}$ & 0.3 & 3.137 .6 & 97.8 & 2.2 & 3155.2 & 97.7 & 2.3 & 2.3 \\
\hline \# 100 & 0.15 & 3.148 .2 & 98.1 & 1.9 & 3162.0 & 97.9 & 2.1 & 2.0 \\
\hline \# 200 & 0.075 & 3.190 .4 & 99.5 & 0.5 & 3210.7 & 99.4 & 0.6 & 0.6 \\
\hline \multicolumn{2}{|c|}{ Weight sample } & 3207.8 & & & 3230.4 & & & \\
\hline
\end{tabular}

Examination of rock ash obtained Bulk specific gravity $2,625 \mathrm{gr} / \mathrm{cc}$, SSD specific gravity 2,678\%, Apparent specific gravity $2,758 \mathrm{gr} / \mathrm{cc}$ and $1,843 \%$ absorption. The results of the sieving analysis can be seen in Table 3 . 
Table 3. Ash stone sieving analysis

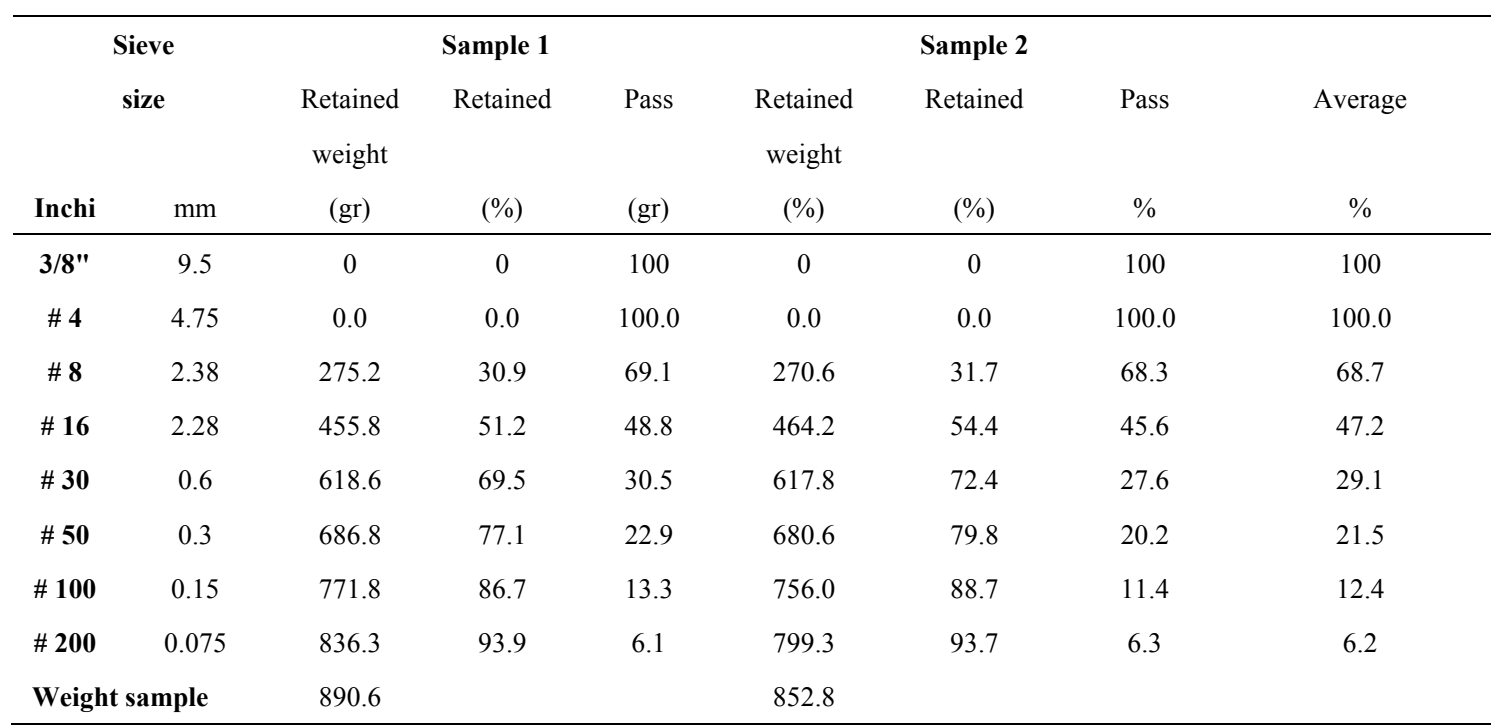

\section{Shell Asphalt Inspection}

The characteristics and properties of Shell oil asphalt used for this research are secondary data from the results of inspections conducted by the Bandung Institute of Technology. The results of the examination can be seen in Table 4 below.

Table 4. Shell asphalt inspection results

\begin{tabular}{|c|c|c|c|c|c|c|}
\hline \multirow{2}{*}{ No. } & \multirow{2}{*}{$\begin{array}{c}\text { Test } \\
\text { Hard asphalt }\end{array}$} & \multirow{2}{*}{ Specification } & \multirow[t]{2}{*}{ Units } & \multicolumn{2}{|c|}{ Asphalt specification } & \multirow{2}{*}{$\begin{array}{l}\text { Test } \\
\text { result }\end{array}$} \\
\hline & & & & Min & Max & \\
\hline 1 & Penetration at temp. $25^{\circ} \mathrm{C}$ & SNI 06-2456-1991 & $0.1 \mathrm{~mm}$ & 60 & 70 & 67.4 \\
\hline \multirow[t]{2}{*}{2} & Flash Point \& & \multirow{2}{*}{ SNI 06-2434-1991 } & \multirow{2}{*}{${ }^{\circ} \mathrm{C}$} & 232 & \multirow[t]{2}{*}{-} & 341 \\
\hline & Fire Point & & & & & 349 \\
\hline 3 & Softening Point & SNI 06-2434-1991 & ${ }^{\circ} \mathrm{C}$ & 48 & 56 & 51 \\
\hline 4 & Specific gravity investigation & SNI 06-2441-1991 & $\mathrm{gr} / \mathrm{cc}$ & 1.01 & 1.06 & 1.039 \\
\hline 5 & Ductility investigation at temp. $25^{\circ} \mathrm{C}$ & SNI 06-2441-1991 & $\mathrm{cm}$ & 100 & - & $>100$ \\
\hline 6 & Losing weight investigation & SNI 06-2440-1991 & $\%$ weight & & 0.2 & 0.0047 \\
\hline 7 & Solubility in TCE & SNI 06-2438-1991 & $\%$ weight & 99 & & 99.75 \\
\hline 8 & Ductility after losing weight & SNI 06-2432-1991 & $\mathrm{cm}$ & 100 & & $>100$ \\
\hline \multirow[t]{3}{*}{9} & Penetration after losing weight & & $0.1 \mathrm{~mm}$ & 50 & 80 & 63.8 \\
\hline & $\begin{array}{l}\text { Percentage of penetration difference } \\
\text { after TFOT; \% genuine }\end{array}$ & SNI 06-2456-1991 & $\%$ & - & 40 & 5.3 \\
\hline & Percentage of genuine penetration & & $\%$ & 54 & & 94.7 \\
\hline 10 & Paraffin content & SNI 03-3639-1994 & $\%$ & & 2 & 0.14 \\
\hline \multirow[t]{4}{*}{11} & Spot Test & & & & & \\
\hline & Standard Naptha & & & Negative & & Negative \\
\hline & Naptha Xylene & & & Negative & & Negative \\
\hline & Hephtane Xylene & & & Negative & & Negative \\
\hline
\end{tabular}

Source: ITB Laboratory Result Test 


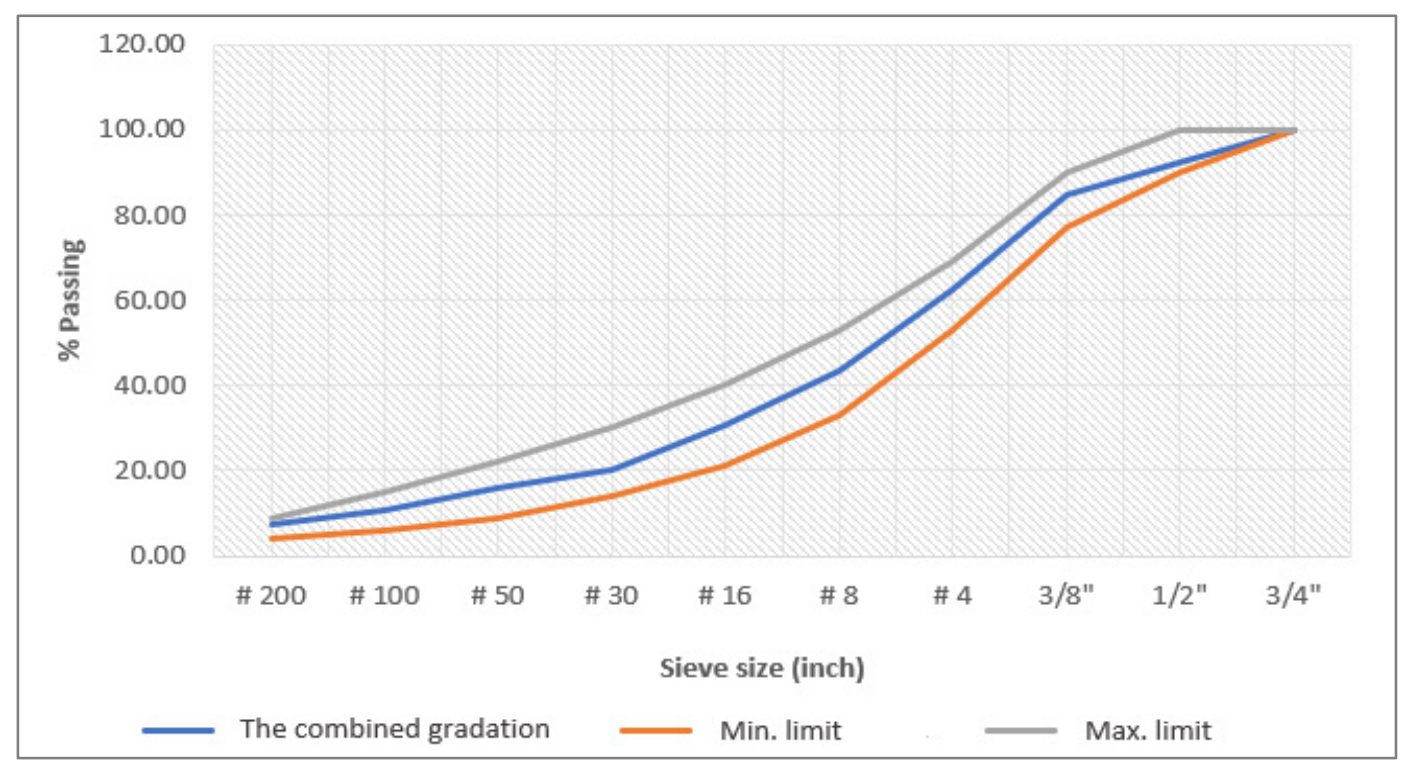

Figure 2. The combined gradation of the extracted RAP aggregate mixture

\section{Mixed Planning}

Asphalt Concrete Wearing Course mixture must meet the requirements of technical specifications, so that good planning is needed between the constituent materials. This mixed planning is intended to determine the amount of aggregate use of RAP extraction, additional aggregate (rejuvenator), and stone ash. Whereas to find the optimum asphalt content, try variations of asphalt content of $4.5 \%$, $5.0 \%, 5.5 \%, 6.0 \%$, and $6.5 \%$ of the total weight of the mixture. Compaction is carried out $2 \times 75$ times, every 75 times for the upper edge and below. To get gradations according to AC-WC specifications, the results of the analysis of the aggregate filter are from the RAP extraction plus the aggregate rejuvenator. After several experiments, a combined gradation is obtained with a proportion of $30 \%$ Aggregate from RAP extraction, 18\% Aggregate 3/4", 50\% stone ash, and $2 \%$ Filler. The combined gradation of the extracted RAP aggregate mixture is presented in Figure 2.

\section{Properties of Asphalt Mixture Variation}

The Marshall test is carried out to determine the quality of the mixture being tested to obtain the value of the amount based on the indicators shown at the time of testing to obtain optimum asphalt content. Testing is carried out in stages following the order of testing to achieve the planned research objectives. In addition to obtaining optimum asphalt content, Marshall test is also used to determine the effect on Marshall properties values i.e. stability, flow, Marshall Quotient (MQ), density, void in mineral aggregate (VMA), void in the mix (VIM), and the void filled with asphalt (VFWA). The stability of all asphalt content was done $4.5 \%-6.5 \%$ already meets the specifications, which have values above $800 \mathrm{~kg}$. Flow value that meets the specifications of $2 \%-4 \%$ is obtained at Asphalt Content of $4.9 \%$ to $6.1 \%$. VMA values at
Asphalt Content of $4.5 \%-6.5 \%$ resulting between 15.64\% to $17.37 \%$ meet the minimum specifications of $15 \%$. VIM values according to specifications are 3\% - 5\% obtained at asphalt content of $5.3 \%$ to $6.5 \%$. VFWA values from Marshall test results obtained values of $54.35 \%$ to $77.41 \%$, the asphalt content that meets the VFWA specifications with a minimum value of $65 \%$ is $5.1 \%-6.5 \%$. Optimum Asphalt Content based on calculations obtained a value of $5.7 \%$. Test results on asphalt content of $5.7 \%$ indicate this mixture has a very good load-bearing ability seen from the Stability value of $1188 \mathrm{~kg}, 148.5 \%$ above the minimum requirement of $800 \mathrm{~kg}$, flow is almost at the upper limit of the requirements which means it has good flexibility but also has sufficient stiffness shown by the MQ value of this mixture $333 \mathrm{~kg} / \mathrm{mm}, 133.2 \%$ above the minimum requirement of $250 \mathrm{~kg} / \mathrm{mm}$. This mixture has a fairly good permeability where the VMA, VIM, and VFWA values of the mixture meet the specification requirements. The Marshall Properties value of the mixture at asphalt content of $5.7 \%$ can be seen in Table 5 .

Table 5. Marshall Properties on Optimum Asphalt Content

\begin{tabular}{llcccc}
\hline No & \multicolumn{1}{c}{ Test } & Result & \multicolumn{2}{c}{ Specification } & Units \\
& & & Min. & Max. \\
\hline $\mathbf{1}$ & Stability & 1188 & 800 & - & $\mathrm{Kg}$ \\
$\mathbf{2}$ & Residual Stability & 1078 & 800 & - & $\mathrm{Kg}$ \\
$\mathbf{3}$ & Flow & 3.57 & 2 & 4 & $\mathrm{~mm}$ \\
$\mathbf{4}$ & Marshall Quotient & 333 & 250 & - & $\mathrm{Kg} / \mathrm{mm}$ \\
$\mathbf{5}$ & VMA & 16.07 & 15 & - & $\%$ \\
$\mathbf{6}$ & VIM & 3.76 & 3 & 5 & $\%$ \\
$\mathbf{7}$ & VFWA & 76.59 & 65 & - & $\%$ \\
\hline
\end{tabular}




\section{Durability Analysis Mixed AC-WC}

The residual stability value was obtained from the Marshall test after the specimens were immersed in a water bath at $60{ }^{\circ} \mathrm{C}$ for 24 hours to see the effect of immersion in water and temperature on the stability value. Table 5 shows the stability of the residual mixture is still above the minimum specification requirements, which means that this mixture has satisfactory durability, is resistant to perpendicular water conditions and a temperature of $60^{\circ} \mathrm{C}$ for 24 hours. Asphalt film layer on the aggregate serves to protect and bind the aggregates with one another. Asphalt content is less than optimum resulting in thin asphalt films and bonding between aggregates become easily separated. The relationship between bitumen content and asphalt film thickness is shown in Figure 3.

Based on Figure 2 it can be seen that the BFT that meets the $8 \mu-9 \mu$ specification is obtained in the asphalt content range of $5.4 \%-6.0 \%$. The BFT value at the optimum asphalt content from the research results obtained $8.4 \mu$ means the mixture has sufficient asphalt film to protect the aggregate and can bind the aggregate well so that it has good durability.

\section{Density Analysis}

Absolute density in this study uses the 2010 Revised version 3 Bina Marga Specification where compaction is carried out $2 \times 400$ collisions. The density at compaction of the mixture is the specific gravity of the mixture. Density is the main important indication regarding pavement porosity. The denser of the pavement produced the greater of the stability. Comparison of mixture density in standard compaction and absolute density. The density value at $2 \mathrm{x}$ 400 collisions have increased by $1.41 \%$, from 2.33 to 2.37 . It can be assumed that the density at the end of the Plan Life is 2.37 , denser than at the beginning of the Plan Life due to compaction of additional vehicle loads passing by.

\section{Void Analysis}

Void in the mixture has an important role. The mixture must have enough void for asphalt expansion to prevent bleeding, that is, asphalt rises above the pavement surface due to the unavailability of sufficient void when expansion occurs. The value of void at maximum density is reviewed at optimum asphalt content plus $0.5 \%$ and reduced by $0.5 \%$. The results showed the greater level of asphalt, the value of the void at absolute density is getting smaller, so the more likely the pavement is bleeding. The optimum asphalt content of the research mixture has a void of $2.4 \%$ exceeding the minimum requirement of $2 \%$ so that we can assume the pavement air cavity at the end of the service life is sufficient to resist the traffic load and anticipate bleeding.

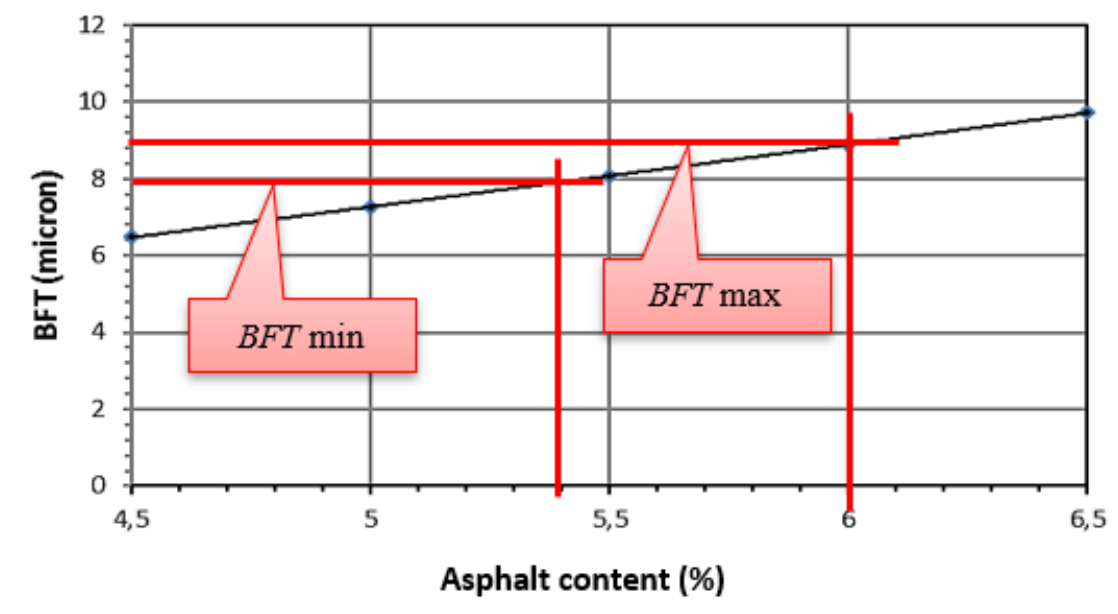

Figure 3. Graph of Comparison of Asphalt Content with BFT 


\section{Conclusions}

Based on the analysis results it can be concluded that The Marshall Properties value of AC-WC mixture using RAP material has good characteristics. The extraction analysis obtained asphalt content is between $3.50 \%$ $4.36 \%$, with abrasion of $29.04 \%$. RAP cannot be used directly but there is a need to add fresh aggregates so that the mixture meets the specifications. The proportion of the mixture is $30 \%$ of RAP, $18 \%$ of the fresh aggregate, $50 \%$ of rock ash, and $2 \%$ of Cement. The analysis showed that the mixture with optimum asphalt content $(5.7 \%)$ obtained $1188 \mathrm{~kg}$ of stability, $4.02 \%$ of VIM, $15.81 \%$ of VMA, $74.54 \%$ of VFWA, and $3.57 \mathrm{~mm}$ of flow. These values indicate that the mixture meets the revised version of the Technical Specifications of Bina Marga 2010. Therefore, it can be said that this mixture has high durability, good density and is resistant to the possibility of bleeding

\section{Acknowledgment}

The authors thank the Directorate of Research and Community Service, Directorate General of Research and Technology Strengthening, Ministry of Research, Technology and Higher Education, Indonesia who has provided grants with contract number: 199.16/A3-III/LPPM/V/2019, and the facilities support of LPPM Universitas Muhammadiyah Surakarta.

\section{REFERENCES}

[1] Abraham, S. M., \& Ransinchung, R. G. (2019). Effects of Reclaimed Asphalt Pavement aggregates and mineral admixtures on pore structure, mechanical and durability properties of cement mortar. Construction and Building Materials, 202-213.

[2] Al-Qadi, I., Elseifi, M., \& Carpenter, S. (2007). Reclaimed Asphalt Pavement - a Literature Review. Illinois Center for Transportation Series No. 07-001. Illinois, US: University of Illinois at Urbana-Champaign.

[3] Fattah, M. Y., Qasim, Z. I., \& Zuhier, Y. A. (2017). Impact of Reclaimed Asphalt Pavement (RAP) on Properties of Asphalt Mixture for Surface Layer. Global Journal of Engineering Science and Research Management, 161-170.

[4] Gudipudi, P., \& Underwood, B. S. (2015). Testing and modeling of fine aggregate matrix and its relationship to asphalt concrete mix. Transportation Research Record 2507, $120-127$.

[5] Huang, B., Li, G., Vukosavljevic, D., Shu, X., \& Egan, B. K.
(2005). Laboratory Investigation of Mixing Hot-Mix Asphalt with Reclaimed Asphalt Pavement. Transportation Research Record 1929, 37-45.

[6] Kou, C., Xiao, P., Kang, A., Mikhailenko, P., Baaj, H., \& $\mathrm{Wu}$, Z. (2017). Methods to Evaluate the Aging Grades of Reclaimed Asphalt Binder. Applied Sciences, 1-17.

[7] Luo, X., Gu, F., Zhang, Y., Lytton, R. L., \& Birgisson, B. (2018). Kinetics-Based Aging Evaluation of In-Service Recycled Asphalt Pavement. UK: Journal of Cleaner Production.

[8] Magfirona, A., Hidayati, N., \& Sunarjono, S. (2017). Review of traffic safety management on a toll road. The 5th International Conference on Engineering, Technology, and Industrial Application (pp. 040022-1-040022-6). Surakarta: AIP Conference Proceedings.

[9] Mardhatila, Anisya, and Zulkarnain A. Muis. Kajian Metode Perencanaan Struktur Perkerasan Daur Ulang. Medan: USU, 2013.

[10] Mato, Hanris. "Karakteristik Sifat Fisik Daur Ulang Lapis Perkerasan Aspal (Pemeliharaan Rutin Jalan Paguyaman Jalan Tabulo Kabupaten Boalemo)." Jurnal RADIAL juRnal perADaban saIns, rekayAsa dan teknoLogi, 2015: 87-102.

[11] Praticò, F. G., Vaiana, R., \& Iuele, T. (2015). Permeable Wearing Courses from Recycling Reclaimed Asphalt Pavement for Low-Volume Roads. Transportation Research Record 2474, 65-72.

[12] Sunarjono, S. (2006). EVALUASI ENGINEERING BAHAN PERKERASAN JALAN MENGGUNAKAN RAP DAN FOAMED BITUMEN. UMS.

[13] Sunarjono, S., \& Hidayati, N. (2018). Mixture design consideration for foamed asphalt using RAP materials. 2017 1st International Conference and Applied Technology. IOP.

[14] Thanya, I. N., Suweda, I. W., \& Putra, G. (2018). Performance of Asphalt Concrete Wearing Course (AC-WC) Utilizing Reclaimed Asphalt Pavement from Cold Milling Bound with 80/100 Pen Asphalt. IOP Conference Series: Materials Science and Engineering. IOP.

[15] Vo, H. V., Park, D. W., Seo, J. W., \& Le, T. H. (2019). Effects of asphalt types and aging on healing performance of asphalt mixtures using induction heating method. Journal Traffic Transportation Engineering, 1-9.

[16] Widodo, Sri, Senja Rum Harnaeni, and Lukman Hakim. "Hasil Bongkaran Perkerasan Jalan sebagai Bahan Lapis Fondasi Jalan Raya." Journal MEDIA KOMUNIKASI TEKNIK SIPIL ISSN 0854-1809 VOLUME 19, NO 1, JULI 2013, 2013: 13-18.

[17] Xiao, F., Li, R., Zhang, H., \& Amirkhanian, S. (2017). Low-Temperature Performance Characteristics of Reclaimed Asphalt Pavement (RAP) Mortars with Virgin and Aged Soft Binders. Applied Sciences, 1-16. 